УДК 343.1

DOI https://doi.org/10.32837/yuv.v0i2.2141

\author{
Р. Климкевич, \\ викладач кафедри кримінально-правових дисциплін \\ Інституту права \\ Львівського державного університету внутрішніх справ
}

\title{
ДИРЕКТИВИ ЯК ДЖЕРЕЛО \\ КРИМІНАЛЬНОГО ПРОЦЕСУАЛЬНОГО ПРАВА ЄВРОПЕЙСЬКОГО СОЮЗУ
}

\begin{abstract}
Постановка проблеми. У сучасному світі спостерігаються тенденціі зближення правових систем різних держав. Це зближення не оминуло увагою і кримінально-процесуальну сферу, яка протягом останніх десятиліть характеризується посиленням співробітництва у кримінальних справах між державами-членами ЄC. Прийняття Лісабонського договору 2009 р. спричинило низку важливих змін, зокрема зміну інституційного механізму ЄC.

Варто зауважити, що ст. 82 цього договору «заклала підвалини» для подальших гармонізаційних перетворень у сфері кримінального процесуального права ЄС. Вищезгадана стаття дає можливість Європейському Парламенту та Раді шляхом директив, прийнятих у спосіб загальної законодавчої процедури, встановлювати мінімальні правила, які повинні враховувати розбіжності між правовими системами та традиціями держав-членів ЄС. Ці правила стосуються: взаємного визнання доказів між державами-членами; прав громадян під час кримінального процесу; прав осіб, постраждалих від злочину; будь-яких інших аспектів кримінального процесу, які визначені Радою заздалегідь в іiі рішенні, прийнятому одноголосно. Як наслідок, значно зросла кількість директив у сфері кримінального процесу, що потребує дослідження їх правової природи.
\end{abstract}

Стан наукової розробки проблеми. Джерела права ЄС досліджували у своїх працях вітчизняні
(О.М. Москаленко, В.I. Муравйов, К.В. Смирнова, В.В. Форманюк, I.В. Яковюк) та російські (М.Л. Ентін, Л.А. Канаєва, С.Ю. Кашкін) науковці. Однак більшість із іхніх досліджень стосуються загальної характеристики джерел права ЄС. На дослідженні гармонізаційних процесів у сфері кримінального процесу зосередили свою увагу B.I. Самарін, Е.M. Сорокіна, А.Ю. Чекотков. Однак комплексні наукові праці, присвячені дослідженню директиви як джерела кримінального процесуального права $\in C$, у вітчизняній науці кримінального процесу відсутні.

Метою статті $€$ аналіз директив Європейського Парламенту та Ради $\in C$ як джерел кримінального процесуального права ЄC, їх ознак та правової природи.

Виклад основного матеріалу. Перш ніж приступити до аналізу директив як джерел кримінального процесуального права ЄС, варто з'ясувати систему джерел права Європейського Союзу загалом та визначити роль та значення директив у ній.

Варто зазначити, що джерела права ЄС досить неоднорідні, що пов'язано зі значною кількістю інституцій $Є C$, які мають компетенцію видавати нормативні акти. Саме тому у науковій літературі немає єдиного підходу до класифікації джерел права Європейського Союзу.

К.В. Смирнова поділяє джерела права ЄC на внутрішні (установчі 
документи; регламенти, директиви, постанови; спільні стратегіі, спільні діï, спільні позиції, рішення та рамкові рішення; нетипові внутрішні джерела рішення, резолюції, декларації Ради; акти представників держав-членів, що об'єднані в Раді; допоміжні конвенції, укладені на підставі ст. 293 Договору про заснування ЄC, та загальні принципи права) і зовнішні (міжнародні угоди з третіми країнами та міжнародними організаціями) [23, с. 7].

O.M. Москаленко обгрунтовує ієрархічну структуру джерел європейського права: перший рівень установчі договори, рішення Ради, загальні принципи права $€ C$; другий рівень - міжнародно-правові зобов'язання Європейських співтовариств та Союзу, які випливають 3 усіх джерел міжнародного права; третій рівень - прецеденти Суду ЄС; четвертий рівень - нормативно-правові акти, що приймаються органами ЄC у рамках Європейських співтовариств, закриті конвенції між державами-членами, які укладаються в рамках Європейських співтовариств, звичаї, сформовані в процесі європейської інтеграції [21, с. 7].

Однак найбільш раціональною та усталеною видається класифікація, представлена С.Ю. Кашкіним. Учений пропонує таку систему джерел права ЄC: а) джерела первинного права (установчі договори Європейського Союзу) б) джерела вторинного права (акти, що видаються інститутами Союзу, а також усі інші акти, прийняті на основі установчих договорів); в) джерела прецедентного права [19, с. 235].

До джерел первинного права слід віднести міжнародні договори установчого характеру (зокрема, Договір про заснування Європейського співтовариства, Договір про заснування Європейського співтовариства 3 атомної енергії, Договір про Європейський Союз 1992 року та інші), конвенції між державами-членами, міжнародні договори ЄС, правові звичаї, традиції.
До джерел вторинного права належать акти інститутів та органів ЄC, прийняті на основі джерел первинного права. Стаття 249 Договору про заснування ЄС зазначає, що Європейський Парламент спільно з Радою, Рада та Комісія виробляють регламенти, видають директиви, створюють рекомендації та надають висновки [18].

Оскільки метою статті $€$ аналіз директив як джерел кримінального процесуального права Європейського Союзу, то варто більш детально розглянути правову природу директив.

Директива Європейського Союзу (European Union Directive) - це законодавчий акт, який зобов'язує держави-члени $Є C$ вжити заходів для досягнення цілей, зазначених у директиві [1, с. 18].

Директиви $€$ одним 3 основних джерел кримінального процесуального права ЄС, мають свої характерні риси, які відрізняють їх від інших джерел вторинного права ЄС.

1. На відміну від регламентів, директиви не підлягають загальному застосуванню, доки вони не адресовані всім державам-членам ЄС. Директиви обов'язкові лише для своїх адресантів. Адресантом може бути окрема країна-член, декілька чи всі країни-члени ЄС. У разі, якщо адресантами є всі країни-члени $€ C$, тоді директива стає загальнообов'язковою. У справі 70/83 Kloppenburg Європейський Суд Справедливості вказав, що «директиви, які адресовані всім країнам-членам $\in C$, є актом, який має загальнообов'язкову юридичну силу» [15].

2. Держави зобов'язані досягти цілей, які зазначені у преамбулі директиви, однак держава має право самостійно вибирати, як і яким чином буде відбуватися інтеграція директиви у правову систему держави. Тим самим підкреслюється, що ЄС встановлює лише цілі та напрями внутрішньодержавних перетворень, а не встановлює, які законодавчі акти повинні бути прийняті [20, с. 185]. Таким 


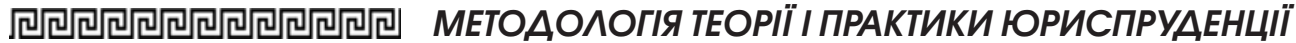

чином, зберігаються особливості національних правових систем, але з посиленням гармонізації та поліпшенням функціонування загальноєвропейських стандартів кримінального процесу.

Зазвичай текст директиви дуже точний та детальний, тому директиви імплементуються у національне законодавство «у чистому вигляді». Як уже зазначалося, основною метою директиви є досягнення визначеного результату. Це означає, що національне законодавство держави-члена $Є C$ повинне відповідати результату, зазначеному у директиві після закінчення терміну імплементації директиви. Імплементація може здійснюватися різними способами: парламентська ратифікація, прийняття підзаконного акта або ж, якщо держава вважатиме це за необхідне та достатнє, прийняття судового рішення [25, с. 165]. Наприклад, аналізуючи імплементацію Директиви про Європейський ордер на проведення розслідування № 2014/41/ EC від 03.04.2014 [12], варто зауважити, що держави-члени ЄС вибрали різні правові форми вираження цих норм у своєму національному законодавстві. Зокрема, це відбувалося шляхом прийняття спеціальних законів про імплементацію директиви та виконання ордеру (Бельгія, Італія, Болгарія); впровадження нових статей у національні КПК (Нідерланди, Латвія, Естонія); впровадження нових статей у національне законодавство, що регулює питання співробітництва у кримінальних справах (Німеччина, Австрія, Угорщина); систематизація всіх імплементаційних актів щодо європейських ордерів в одному законі (Іспанія) [17, с. 567-576].

Цікаво, що часткова та вибіркова імплементація директиви суперечить загальним принципам права EC. Аналогічно імплементація не може обмежуватися лише частиною території певної держави-члена. У справі С-157/89 Комісії проти Італії Європейський Суд Справедливості вказав, що держава-член ЄC не може посилатися на автономію певних регіонів для того, щоб уникнути імплементації деяких положень директиви [14].

3. Держава відповідальна за імплементацію директиви у національне законодавство. Зазвичай передбачається певний проміжок часу, необхідний для імплементації директиви у державі-члені ЄC. Директива набуває чинності у термін, який зазначений у самій директиві. Якщо ж у директиві не передбачено цього терміну, то зазвичай цей термін не перевищує 2 роки. У цьому аспекті регламент має перевагу над директивою, оскільки не завжди держави-члени ЄC вчасно імплементують норми директиви у своє національне законодавство.

4. Директива покладає обов'язок на держави-члени надати перелік заходів, які були вжиті для реалізації вимог директиви. Коли держава-член не повідомила Комісію або подала неповне повідомлення, то це буде порушенням ст. 4 Договору про функціонування Європейського Союзу, у якій вказано, що «держави-члени вживають усіх належних заходів, загальних або спеціальних, щоб забезпечити виконання зобов'язань, що постають 3 Договорів або випливають 3 актів установ Союзу» [2], навіть якщо такі заходи були вжиті. За інших обставин має право подати позов перед судом ЄС. Приміром, строк для імплементації Директиви про Європейський охоронний ордер 2011/99/ЄС від 13.12 .2011 р. закінчився 11 січня 2015 р. Після цього строку деякі держави-члени $\in C$ не повідомили Комісію про вжиті заходи (Бельгія, Болгарія, Чехія, Румунія, Словенія, Фінляндія та інші). Тому у березні 2015 р. Комісія ініціювала відповідні процедури щодо цих усіх держав за невиконання ï обов'язку щодо повідомлення про вжиті заходи для імплементації норм директиви у національне законодавство. Як наслідок, до жовтня 2017 р. усі держави-члени ЄС, на яких поширюється дія норм Директиви, повідомили Комісію про вжиті заходи 
для імплементації норм у національне кримінальне процесуальне законодавство [16].

5. Директива $є$ реалізацією принципу субсидіарності, який $€$ «одним 3 нормативних постулатів європейської інтеграції» [24; 25]. Адже якщо приймається директива, то деталі, які нею не охоплені, залишаються на розсуд держав-членів ЄС. Очевидно, що недоцільно на європейському рівні забезпечувати надмірну деталізацію регулювання суспільних відносин, зокрема і в кримінальній процесуальній сфері. Саме тому прийняття такого інструменту, як директива, варто вважати реалізацією принципу субсидіарності.

Якщо директива не була імплементована у національне законодавство, то це породжує такі правові наслідки:

а) вона підлягає прямому застосуванню після закінчення терміну, призначеного для iї імплементації;

б) особа має право посилатися на положення директиви у національних судах;

в) Комісія має право подати позов протидержавизапорушення нормправа ЄC (стаття 258 Договору про Функціонування Європейського Союзу).

Можна виокремити такі директиви, прийняті у сфері кримінального процесу:

1. Директива про право на переклад у кримінальному процесі 2010/64/ ЄС від 20.10.2010 [7].

2. Директива про Європейський охоронний ордер 2011/99/ЄС від 13.12.2011 [8].

3. Директива про право на отримання інформації в кримінальному провадженні 2012/13/ЄC від 22.05.2012 [10].

4. Директива про встановлення мінімальних стандартів прав, підтримки та захисту потерпілих 2012/29/ ЄС від 25.10.2012 [9].

5. Директива про право на доступ до адвоката в кримінальному процесі та в процедурі, пов'язаній з Європейським ордером на арешт, і про право на повідомлення третьої особи про позбавлення волі і про спілкування $з$ третіми особами та консульськими співробітниками у разі утримання під вартою 2013/48/ЄС від 22.10.2013 [11].

6. Директива про Європейський ордер на проведення розслідування у кримінальних справах 2014/41/ EC від 03.04.2014 [12].

7. Директива про заморожування i конфіскацію засобів вчинення та доходів від злочинів у Європейському Союзі 2014/42/ЄС від 03.04.2014 [13].

8. Директива про посилення деяких аспектів презумпції невинуватості і право бути присутнім у суді в ході кримінального судочинства 2016/343/ ЄС від 09.03.2016 [4].

9. Директива про захист фізичних осіб щодо обробки їхніх персональних даних компетентними органами в цілях попередження, розслідування, виявлення та переслідування кримінальних злочинів чи виконання кримінальних покарань, а також вільної передачі таких даних 2016/680 від 27.04.2016 [5].

10. Директива про процесуальні гарантії для неповнолітніх підозрюваних чи обвинувачених у кримінальному провадженні 2016/800 від 11.05.2016 [6].

11. Директива про правову допомогу підозрюваним та обвинуваченим у кримінальному провадженні, а також особам, до яких застосована процедура Європейського ордеру на арешт 2016/1919 від 26.10.2016 [3].

Як можна зрозуміти із назв зазначених вище директив, більшість 3 них спрямована на гарантування процесуальних прав учасників кримінального провадження, а також запровадження інструментів міжнародного співробітництва у кримінальних справах. Проаналізувавши сфери гармонізації кримінального процесуального законодавства, В.І. Самарін зробив висновок про те, що вони спрямовані на: 1) забезпечення довіри до прийнятого в інших 


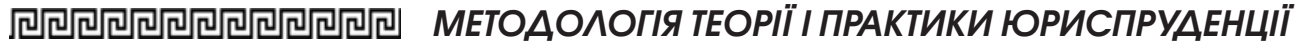

державах-членах судового рішення; 2) створення єдиної культури судового процесу з метою забезпечення громадянам одної держави-члена єдиних мінімальних прав у разі залучення їх у сферу кримінального процесу іншої держави-члена [22, с. 258].

На підставі проаналізованих вище ознак та властивостей директив загалом та зазначених конкретних директив у сфері кримінального процесу можемо запропонувати власну дефініцію. Директива як джерело кримінального процесуального права EC - це вторинне джерело права $\in C$, яке спрямоване на гармонізацію кримінального процесуального права держав-членів ЄС, що зобов'язує держави-члени ЄC вжити заходів для досягнення визначених у ній цілей та приймається щодо конкретних сфер кримінального процесу, які визначені у ст. 82 Договору про функціонування Європейського Союзу.

Висновки. Таким чином, прийняття Лісабонського договору 2009 р. спричинило низку важливих змін, таких як скасування «третьої опори» та скасування режиму спільного прийняття рішень. Це своєю чергою дало можливість приймати законодавчі акти, що стосуються питань кримінального процесу у спосіб загальної законодавчої процедури (кваліфікованою більшістю). Ст. 82 цього договору чітко окреслила коло правових питань, щодо яких можуть прийматися директиви у сфері кримінального процесу.

Внаслідок цих процесів директива стала основним правовим актом у сфері кримінального процесу. Про це свідчить ї кількість, адже станом на сьогодні налічується понад десять директив у зазначеній сфері. Більшість 3 цих директив стосуються правової регламентації процесуальних прав учасників кримінального провадження (зокрема, права на переклад, права на інформацію, права на правову допомогу та інші), а також запровадження інструментів міжнародного співробітництва.
Прийняті директиви свідчать про тенденції до більш глибокої гармонізації кримінальних процесуальних норм у межах інтеграційного утворення і подальшої європеїзації національного кримінального процесуального права держав-членів ЄС.

у статті досліджено одне з основних джерел кримінального проиесуального права ЄC - директиви Європейського Парламенту ma Ради EC. Зазначені різні наукові підходи до класифікаиіi джерел права ЄC, однак найбільш прийнятним вважаємо поділ джерел права EC на первинні та вторинні.

У статті проаналізовані ознаки директив як джерела кримінального процесуального права ЄС. Однією з основних ознак директив є закріплення у них загального результату, якого необхідно досягнути із наданням можливості державам-иленам самостійно вибирати иляхи та способи досягнення цьього резульmamy. Окрім иього, до інших ознак директиви належить конкретний часовий ліміт для імплементації $і ̈$ норм, а також настання різних правових наслідків у разі невиконання державою-иленом цього обов'язку. До останніх сліо віднести пряме застосування норм директиви після закінчення терміну, призначеного для ї̈ імплементації, та можливість особи посилатися на норми директиви у національних судах.

Щодо імплементації норм директиви у національне законодавство, то держави також вільні у виборі способів та методів. Це може відбуватися иляхом прийняття спеиіальних законів про імплементацію директиви, впровадженням нових статей у національні КПК, впровадженням нових статей у національне законодавство, що регулюе питання співробітництва у кримінальних справах.

У статті перелічені всі чинні натепер директиви у сфері кри- 
мінального процесу. Більшість 3 изих директив стосуються правової регламентації процесуальних прав учасників кримінального провадження (зокрема, права на переклад, права на інформацію, правана правову допомогу та інші), а також запровадження інструментів міжнародного співробітництва (наприклад, Європейського ордеру на проведення розслідування). На основі проведеного аналізу ознак директиви запропоновано власну дефініцію директиви як джерела кримінального прочесуального права ЕС.

Ключові слова: директива ЄC, кримінальне процесуальне право ЄC, імплементація, держави-члени $\in C$, джерело права.

Klymkevych R. Directive as a source of EU criminal procedural law

One of the main sources of $E U$ criminal procedural law - the directives of the European Parliament and the Council of the EU are examined in the article. There are various scientific approaches to the classification of sources of EU law, but we consider the most acceptable classification into primary and secondary sources of law.

The article analyzes the features of directives as a source of EU criminal procedure law. One of the main features of the directives is fixing of the general result, which must be achieved by enabling Member States to choose the ways and methods of achieving this result. Besides, other feature of the Directive is a specific time limit for the implementation of its norms, as well as different legal consequences in the case when Member State failure to fulfil this obligation. The latter include the direct application of Directive's norm after the expiry of the time limit prescribed for its implementation and the possibility for a person to refer to Directive's norms in national courts.
Concerning the implementation of the directive's norms into national law, states are also free to choose ways and methods. It can be done through the adoption of special laws on the implementation of the directive, the introduction of new articles into national CCPS, the introduction of new articles into national legislation regulating the issues of cooperation in criminal matters.

The article lists all current directives in the field of criminal procedure. Most of these directives concern the legal regulation of the procedural rights of participants of criminal proceedings (in particular, the right to translation, the right to information, the right to legal aid, etc.), as well as the introduction of international cooperation instruments (for example, the European Investigation Order). Based on the analysis of the features of the directive, the own definition of the directive as a source of $E U$ criminal procedure law is proposed.

Key words: EU directive, EU criminal procedural law, implementation, EU member state, source of law.

\section{Література}

1. Bailey A.R. The EU Directive Handbook: Understanding the European Union Compliance Process and What it Means to You. CRC Press, 1997. 216 p.

2. Consolidated version of the Treaty on the Functioning of the European Union. OJ C 326, 26.10.2012, p. 47-390.

3. Directive (EU) 2016/1919 of the European Parliament and of the Council of 26 October 2016 on legal aid for suspects and accused persons in criminal proceedings and for requested persons in European arrest warrant proceedings. OJ L 297, 4.11.2016, p. 1-8.

4. Directive (EU) 2016/343 of the European Parliament and of the Council of 9 March 2016 on the strengthening of certain aspects of the presumption of innocence and of the right to be present at the trial in criminal proceedings. OJ L 65, 11.3.2016, p. 1-11.

5. Directive (EU) 2016/680 of the European Parliament and of the Council of 27 April 2016 on the protection of natural persons with regard to the processing of per- 


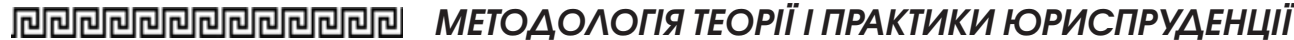

sonal data by competent authorities for the purposes of the prevention, investigation, detection or prosecution of criminal offences or the execution of criminal penalties, and on the free movement of such data, and repealing Council Framework Decision 2008/977/ JHA. OJ L 119, 4.5.2016, p. 89-131

6. Directive (EU) 2016/800 of the European Parliament and of the Council of 11 May 2016 on procedural safeguards for children who are suspects or accused persons in criminal proceedings. OJ L 132, 21.5.2016, p. 1-20.

7. Directive 2010/64/EU of the European Parliament and of the Council of 20 October 2010 on the right to interpretation and translation in criminal proceedings. OJ L 280, 26.10.2010, p. 1-7.

8. Directive 2011/99/EU of the European Parliament and of the Council of 13 December 2011 on the European protection order. OJ L 338, 21.12.2011, p. 2-18

9. Directive 2012/29/EU of the European Parliament and the Council of October 2012 establishing minimum standards on the rights, support and protection of victims of crime, and replacing Council Framework Decision 2001/220/JHA. OJ L 315, 14.11.2012, p. 57-73.

10. Directive 2012/13/EU of the European Parliament and of the Council of 22 May 2012 on the right to information in criminal proceedings, OJ L 142, 1.6.2012, p. 1.

11. Directive 2013/48/EU of the European Parliament and of the Council of 22 October 2013 on the right of access to a lawyer in criminal proceedings and in European arrest warrant proceedings, and on the right to have a third party informed upon deprivation of liberty and to communicate with third persons and with consular authorities while deprived of liberty. OJ L 294, 6.11.2013, p. 1-12.

12. Directive 2014/41/EU of the European Parliament and of the Council of 3 April 2014 regarding the European Investigation Order in criminal matters, OJ L 130, 1.5.2014, p. 1-36.

13. Directive 2014/42/EU of the European Parliament and of the Council of 3 April 2014 on the freezing and confiscation of instrumentalities and proceeds of crime in the European Union, OJ L 127, 29.4.2014, p. 39-50.

14. Judgment of the Court of 13 December 1991. Commission of the European Communities v Italian Republic. Case C-33/90. European Court Reports 1991 I-05987. ECLI identifier: ECLI:EU:C:1991:476.
15. Judgment of the Court of 22 February 1984. Gerda Kloppenburg v Finanzamt Leer. Case 70/83. European Court Reports 1984-01075. ECLI identifier: ECLI:EU:C:1984:71.

16. Report from the Commission to the European Parliament and the Council on the implementation of Directive 2011/99/EU of the European Parliament and of the Council of 13 December 2011 on the European protection order. COM / 2020/187 final.

17. Бирюков П.Н. Имплементация в государствах-иленах Европейского Союза правил о Европейском следственном ордере. Вестник Санкт-Петербургского университета. Право. Т. 10. Bun. 3. 2019. С. 566-576.

18. Договір про заснування Європейської Спільноти (консолідована версія станом на 1 січня 2005 рокy). URL: https: / / zakon.rada.gov.ua/laws/show/994_017.

19. Кашкин С.Ю, Калиниченко П. А., Четвериков А.О. Введение в право Европейского Союза : учебник. Москва : Эксмо, 2008. 384 c.

20. Климкевич Р. Директиви як джерело кримінального процесуального права Європейського Союзу. Проблеми державотворення $i$ захисту прав людини в Україні : матеріали XXV звітної науково-практичної конференції, 7-8 лютого 2019 р. Львів, 2019. С. 185-187.

21. Москаленко О.М. Джерела права Eвропейського Союзу: міжнародно-правовий аналіз : автореф. дис. ... канд. юрид. наук : спеи. 12.00.11. «Міжнародне право». Київ. 2006. 17 с.

22. Самарин B.И. Oпьм Европейского Союза по гармонизации уголовно-процессуального права. Европейский Союз и Республика Беларусь: перспективы сотрудничества. The European Union and the Republic of Belarus: Getting Closer for Better Future : сборник тезисов докладов II Международной конферениии. Минск, 2 июня 2016 г. / редкол.: В.Г. Шадурский и др. Минск : Изд. иентр БГУ. 2017. C. 258-259.

23. Смирнова К.В. Джерела права Європейського Союзу : автореф. дис. ... канд. юрид. наук : спеи. 12.00.11. «Міжнародне право». Київ, 2005. 14 с.

24. Трагнюк О.Я. Принщип субсидіарності за Європейською Конвенцією про захист прав $і$ основних свобод людини 1950 р. Право України. 2003. № 1. С. 25-26.

25. Халиев K.P. Нормативная сила «директив» EC. Актуальные проблемы экономики и права. 2008. № 3. С. 163-166. 